\title{
The Role of Ecotones in Emerging Infectious Diseases
}

\author{
Dickson Despommier, ${ }^{1}$ Brett R. Ellis, ${ }^{2}$ and Bruce A. Wilcox ${ }^{2}$ \\ ${ }^{1}$ Department of Environmental Health Sciences, Mailman School of Public Health, Columbia University, New York, NY 10032 \\ ${ }^{2}$ Department of Tropical Medicine, Microbiology, and Pharmacology, School of Medicine, University of Hawaii at Kaka'ako, Honolulu, HI 96813
}

\begin{abstract}
Recognition of the significance of the boundary between ecological systems, often referred to as the ecotone, has a long history in the ecological sciences and in zoonotic disease research. More recent research in landscape ecology has produced an expanded view of ecotones and elaboration of their characteristics and functions in ecosystems. Parallel research on emerging infectious diseases (EIDs) and the causes of increased rates of pathogen transmission, spread, and adaptation suggests a correspondence between ecotonal processes and the ecological and evolutionary processes responsible for zoonotic and vector-borne emerging infections. A review of the literature suggests that ecotones play a role in a number of the most important EIDs. Yet these are the only diseases for which specific landscape ecological information exists in the literature or disease reports. However, the similar disease ecologies of these with about half of the approximately 130 zoonotic EIDs suggests ecotones, particularly their anthropogenic origination or modification, may be generally associated with ecotones and the global trend of increasing EIDs.
\end{abstract}

Key words: ecotones, EIDs, emerging infectious diseases

\section{INTRODUCTION}

Ecotones, the edges or transition zones between two adjacent ecological systems are frequently mentioned in the zoonotic and vector-borne disease literature. They are used to describe field study or sampling locations (Bennett et al., 1999; Townsend et al., 2003; Eisen et al., 2004) and features of possible surveillance value using remote sensing (Wilson, 2002b). Some recent field studies have suggested ecotones as habitats where rates of infectious parasitic diseases in wildlife are high and may increase due to climate-driven shifts in ecotones (Svobodova et al., 2004). Studies in Europe and North America have shown tick vectors of a number of significant zoonotic infectious diseases are most

Published online: December 7, 2006

Correspondence to: Dickson Despommier, e-mail: ddd1@columbia.edu abundant in these ecotones (Goddard, 1997; Lindstrom and Jaenson, 2003; Pietzsch et al., 2005). Mosquitoes responsible for the transmission of encephalitis virus have been found to congregate at ecotones (Lothrop et al., 2002), and populations of competent rodent reservoirs (whitefooted mouse) for Lyme disease preferentially inhabit ecotones (LoGiudice et al., 2003). Ecotones have been identified as potentially important for some eukaryotic parasites in terms of host seeking (Burg, 2001) and host switching (Hoberg et al., 2002). The pathogen's themselves may concentrate in their host populations at ecotones as is apparent for some arboviruses (Yuill, 1986). Bradley (2004) briefly summarized the history of ecotones in epidemiology with regard to their significance in providing specialized habitat for hosts or vectors, as the interface between human settlements and natural ecosystems, and where humans come in contact with a "new" ecosystem. However, his 
focus was on an analogous concept he coined "chronotones," and their potential for contributing to understanding disease outbreaks and control measures targeting environmental factors. Yet the role of ecotones as a factor contributing to the global EID phenomenon has not been critically examined taking into account the synthesis based on a re-examination of ecotones based by landscape ecologists (Holland et al., 1991; Hansen and Di Castri, 1992; Risser, 1995). In this article, we briefly summarize this expanded view of ecotones and consider the evidence based on a review of the literature and EID reports for the role of ecotones in infectious disease emergence on this basis.

\section{EXPANDED VIEW OF ECOTONES}

Ecotones were originally described as specialized wildlife habitat represented by readily identifiable edges or transitions zones between major vegetation cover types (Clements, 1905; Leopold, 1933; Odum, 1971). They were viewed as relatively static zones and landscape boundaries favored as habitat by some species and crossed by other species encroaching "alien" habitat or ecosystems. In the new synthesis (Holland et al., 1991; Hansen and Di Castri, 1992; Risser, 1995), ecotones are described as dynamic and more complex constituents of ecological systems that influence biodiversity and ecosystem function disproportionately to their geographic extent, and all spatial scales. This new synthetic view has been substantiated by theoretical and empirical studies (Smith et al., 1997; Fagan et al., 1999).

The principle conclusion of this body of research is that ecotones can now be described as areas where biophysical factors, biological activity, and ecological evolutionary processes are concentrated and intensified. This includes biological productivity, genetic diversification, evolutionary adaptation, interspecific interactions, and the aggregation and movement of organisms, nutrients, and other materials (Risser, 1995), although a single ecotone may not exhibit all these characteristics (Walker et al., 2003). Another dimension of this rethinking of ecotones is their description as representing a spatial hierarchy (Gosz, 1991, 1993). Thus, an ecotone can be considered the boundary at an individual plant's edge or a small vegetation patch (on the scale of meters or hectares) to a landscape type (on the scale of $10^{4}$ to $10^{6}$ hectares) or that determined by the transition zone between two biomes (a regional scale of $10^{3}+\mathrm{Km}^{2}$ ). This biome, or regional scale ecotone con- sists of a landscape "mosaic" of patches varying in type, number, size, inter-patch distance, and juxtaposition. Its ecotone characteristics reflect a spectrum of patch ecotonal and inter-patch processes depending on the microclimate, soil chemistry, flora and fauna, as well as larger scale abiotic and biotic factors, including human influences across all of these scales.

It follows that ecotones include zones of interaction where large-scale land use change produces moving "fronts" where human settlements and accompanying cropland and pasture expand into relatively intact natural ecosystems. Such ecotones now dominate much of the geography of the world's tropical developing regions where land use change and forest conversion has been occurring at historically unprecedented rates in the past three decades (Meyer and Turner, 1994; Lambin et al., 2003). Humancreated ecotones now extend across entire regions, superimposed on and expanding into natural ecotones, as well as extending deep into formerly intact blocks of continuous forest. Much of the formerly huge block of tropical rain forest extending across equatorial, central, and East Africa has been eroded to a point where all but the core area in central Africa can be described as basically a regional scale ecotone. Population growth and pressure on natural resources has similarly transformed Southeast Asia in recent decades such that zones representing ecotones are now far more extensive than intact forest blocks. This may limit the original utility of the term (edge habitat has become virtually ubiquitous) on this scale. But it emphasizes how processes formerly constrained geographically are now widespread.

\section{Ecotonal Processes and the Disease Emergence Process}

Dazsak et al. (2000) described how most emerging infectious diseases exist within a host-parasite ecological continuum, while Patz et al. (2000) summarize the types of environmental changes and conditions known to have contributed to emerging zoonotic infectious diseases. These authors and others (e.g., Lafferty and Kuris, 1999; Wilcox and Colwell, 2005; Wilcox and Gubler, 2005) have suggested how parasite-vector-host relationships can be distorted by anthropogenic landscape alterations that contribute to changes in vector breeding conditions in nonhuman and human host populations, resulting in shifts in host-vector-parasite relationships. Kapan et al. (2006) 
Table 1. Correspondence of Ecotone Characteristics and Processes with Ecological Evolutionary and Host-Vector-Parasite Changes Associated with Zoonotic Disease Emergence

\begin{tabular}{llc}
\hline $\begin{array}{l}\text { Biophysical factors reportedly } \\
\text { elevated in ecotones }\end{array}$ & $\begin{array}{l}\text { Ecological or evolutionary } \\
\text { condition or change }\end{array}$ & $\begin{array}{l}\text { Host-Vector-Parasite (pathogen) shifts or } \\
\text { change producing disease emergence }\end{array}$ \\
\hline $\begin{array}{l}\text { 1. Species richness and density } \\
\text { 2. Genetic variability and diversity }\end{array}$ & $\begin{array}{l}\text { Increased frequency of novel } \\
\text { species contact } \\
\text { Increased opportunity for genetic } \\
\text { exchange, genetic novelty } \\
\text { Increased population growth } \\
\text { and turnover rates }\end{array}$ & $\begin{array}{c}\text { Increased opportunity for host-switching } \\
\text { by pathogens } \\
\text { Increased rates of evolutionary change } \\
\text { and adaptation }\end{array}$ \\
$\begin{array}{ll}\text { 3. Biological productivity } & \text { Dispersal and regulation of movement } \\
\text { and flows of species, water, and materials } & \text { critical thresholds for pathogen/infection } \\
\text { growth and persistence in host population } & \text { Increased opportunity for pathogen and host } \\
\text { dispersal via environmental media } \\
\text { flows of energy, materials, }\end{array}$ & (water, air, soil/sediment)
\end{tabular}

5. Environmental variability and Spatial and temporal environmental gradients; habitat heterogeneity

variation in biotic and abiotic factors

describe this in detail for avian influenza (H5N1), describing how microscale ecological evolutionary and macroscale social ecological changes may be linked.

As shown in Table 1, the biophysical factors, biological activity, and ecological evolutionary processes described by ecologists and evolutionary biologists as characteristic of, and concentrated and intensified in, ecotones are largely the same factors thought to contribute to the shifts or changes in hosts, vectors, or parasites (pathogens) that produce disease emergence. These dynamics are associated with land cover/use change and the changing nature of the land-water interface, where parasite and host switches can occur as either "spillover," cross-species transmissions, or introductions/extensions of geographic range into new or changed habitats (e.g., Patz et al., 2004). Anthropogenic influences reflected in land use/cover change can be described as effectively increasing ecotonal processes by increasing their geographic extent and overlap. The result is often in the intersection of multiple natural and anthropogenic types of ecotones.

Human activity has resulted in the spatial hierarchy of "ecotones within ecotones" being elaborated across scales from that of local habitat patch to the biome, produced by different combinations of natural and anthropogenic habitat and ecosystem types. For example, at the local to landscape scale, these include forest edge habitat and fragmented forest landscapes, and terrestrial-aquatic ecotones represented by riparian habitat and riverine landscapes, and wetland (fresh water and estuarine). At the biome scale, these primarily include forest-grassland/tundra and terrestrial-marine (coastal zone) ecotones. Anthropogenic ecotones recognizable at the local to landscape scale include cropland/pasture-natural habitat and settlement-natural habitat, and a combination of these. The mixture of different kinds of cropland, pastureland, and natural habitat, with different human settlement types (urban, peri-urban, or rural) coalesce into complexes of ecotones on a regional scale.

\section{Emerging Infectious Diseases Associated WITH ECOTONES}

It follows that ecotones and their associated processes may play a role in the EID phenomenon. Particularly for those zoonotic diseases whose emergence has been adequately documented, there should be a demonstrable association with ecotones and specific ecotonal processes. We attempted to test this hypothesis by searching the peer reviewed literature for relevant information on the list of 130 zoonotic EIDs assembled by Taylor et al. (2001), recently updated by Woolhouse and Gowtage-Sequeria (2005). We reviewed the readily accessible (electronically searchable) literature on each disease for information describing the locations, ecological circumstances, and factors reported to have contributed to emergence events. Consistent with the definition of an EID (Lederberg et al., 2003), we attempted to determine whether or not the source or appearance of a new or more virulent variant of a pathogen, infection event, 


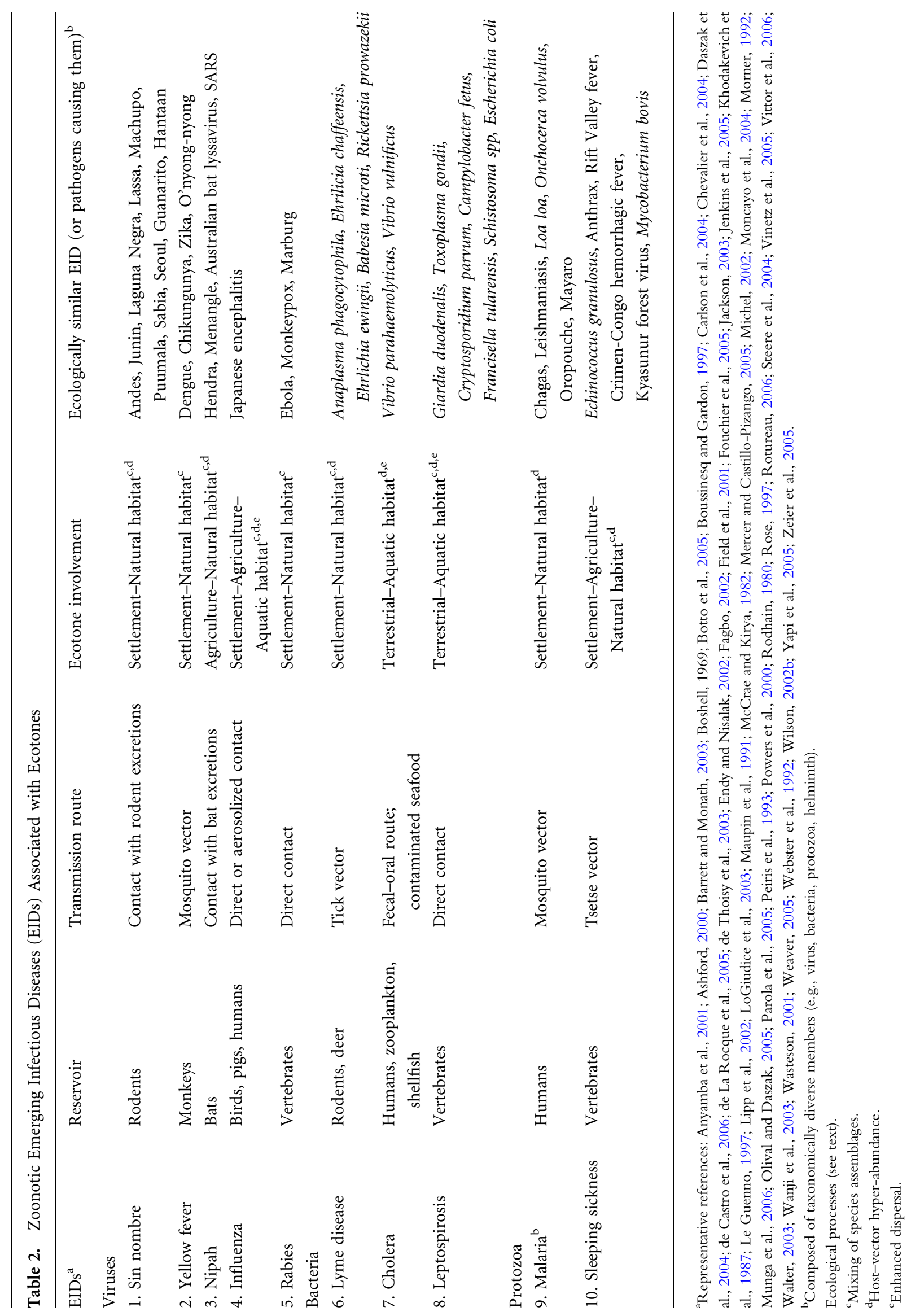


outbreak or epidemic(s), dispersal or geographic spread of a pathogen has been or still is associated with an ecotone. In addition, we attempted to further determine whether specific ecotonal processes are suggested. For some diseases, an association with ecotones is well-know and has been explicitly described (e.g., Yellow fever and Lyme disease). However, neither this terminology nor other technically precise landscape ecological terminology, or technically precise ecological terminology in general is used in the zoonotic disease literature. So whether or not an association with ecotones and specific ecotonal processes exists can only be inferred for many diseases. For most, however, pertinent descriptive information, regardless of its technical precision, currently is lacking altogether.

Table 2 provides a summary of our results including citations of sources representative of the literature for each zoonotic EID where information pertinent to the emergence ecology of a disease and an association with ecotones was found, inferred, or, in a few cases, suggested that further investigation may establish a role for ecotones. Such information, particularly that definitively showing ecotone involvement or not, is generally sparse except for the most thoroughly studied diseases. We found 10 EIDs for which, in our judgment, sufficient information exists and research has been conducted to assess whether or not ecotones contribute to their emergence, at least over a significant part of the diseases' geographic range. Ecotones and ecotonal processes are associated with the emergence of all the viral diseases in Table 2 and one of the bacterial diseases (Lyme disease). For the remaining four diseases, ecotones appear to play a somewhat less important but still significant role. For example, cholera has an oral-fecal transmission mode but the pathogen's dispersal in the environment often involves aquatic-terrestrial ecotonal processes. Also, malaria involves domestic vector-borne transmission in urban environments as well as transmission in rural areas where forest land use change produces more favorable vector habitat along forest edge ecotones contributing to increased vector abundance.

Although information on the landscape ecological circumstances surrounding emergence was found to be sufficient for only these 10 diseases, for each of these, also shown in Table 2, several other diseases are listed whose emergence ecology is apparently similar. For example, like influenza, the emergence of Japanese Encephalitis has involved transmission among birds and pigs (also mosquitoes in the latter) and the spatial overlap of human settlements, agriculture, and natural habitat. They differ in that water- birds and wetland habitat are involved in former while non-water birds but irrigation systems providing vector habitat apparently have been important in the latter's emergence. For some of these ecologically similar diseases, the indirect evidence of a role for ecotones is reasonably strong; for example, for the waterborne diseases listed as similar to cholera and leptospirosis, for which ecotones defined by terrestrial-aquatic (and marine for cholera) ecotones clearly play a role in emergence. For others, like Ebola, Monkeypox, and Marburg, listed as similar to rabies, the data is very sparse, the evidence is weaker, and the similarity is less obvious. But the accumulating evidence points toward the role of forest clearing, increasing edge habitat, encroaching human settlements, and direct human-wildlife contact.

In addition to identifying the particular type of ecotone, we indicated the ecotone characteristics or ecotonal processes apparently contributing to emergence for the 10 well-studied diseases based on our interpretation of the literature. One or a combination of two or more ecotonal processes shown in Table 2, keyed to table footnotes with c, $\mathrm{d}$, and/or e next to the type of ecotone, indicate the following kinds of processes: (c) Mixing of species assemblages_-populations of species that normally are members of distinct ecological communities from different habitats or ecosystems, overlapping in ecotones, providing the opportunity for pathogen spillover. (d) Host-vector hyperabundance-habitat conditions at ecotones providing for unusually high population sizes of actual or potential host or vector species, allowing for the increased potential for pathogens to achieve critical threshold density (i.e., intrinsic rate of infection, $\mathrm{R}_{0} \geq 1$ ). (e) Enhanced dispersal-conditions facilitating dispersal at a higher rate or longer distance, resulting from linear habitat defined by habitat edges, such as riverine or gallery forest, and flowing water in streams or rivers themselves.

Of the 10 known ecotone-associated zoonotic EIDs, the role of ecotones is best documented for Yellow fever. Its ecology and epidemiology has been well described since the mid-1950s and it serves as a classic example of a vectorborne EID associated with an ecotone. The virus is maintained endemically among canopy dwelling monkey species and forest mosquito transmission cycles and may emerge in areas in which human settlement has encroached along the forest fringes, and whose proximal habitations or plantations (e.g., banana) may support domestic and peridomestic Aedes spp. of mosquitoes. The mixing of densely populated host and vector species facilitates the efficiency 
virus transmission, and disease outbreaks frequently occur successively at multiple points along riverine forests. Dengue is a related arboviral disease that has historically shared similar host, vectors, and ecological niche that is now transmissible in the absence of non-human primate cycles. Yet this disease is believed to have originally emerged as a result of the virus' successful shift from forest mosquito species to domestic and peri-domestic mosquito species. Data are insufficient to determine whether or not sylvatic dengue still spills over to peri-domesic transmission cycles. Both of these are examples of spillover from enzootic foci within natural forest ecosystems into proximal human settlements.

Of the other vector-borne EIDs with demonstrable ecotonal associations, Lyme disease is the most thoroughly studied from an ecological perspective. For this tick-borne disease, a complex set of mechanisms involving the affect of fragmented forest-including that of forest edge habitat on the abundance the pathogen's most competent vector (white-footed deer mice)—on host and non-host mammal community abundance and composition explains disease emergence (LoGuiodice et al., 2003). A number of other rodent-borne EIDs potentially can be explained by this or similar ecological mechanisms, although limited or no ecological research has been conducted. Rodents are wellknow to frequently undergo what ecologists call "ecological release" when forest edge and clearings, as well as cropland, is created. In addition, human settlements provide abundant nesting, feeding, and breed sites for rodents and arthropods. Both groups have numerous species apparently pre-adapted to peri-domestic or domestic circumstances, often involving amplification of transmission via domestic animals. Thus arboviral EIDs such as Rift Valley fever, and Venuzuelan Equine Encephalitis probably are ecotone associated. Nipah virus is a clearly documented example of amplification via agricultural encroachment into tropical forest; in this case for the dual purpose of establishing mango plantations and the raising of pigs (Olival and Daszak, 2005).

Sin Nombre virus is a rodent-borne (deer mouse) disease that was first recognized in the four corners region of the United States in the early 1990s. It caused a particularly virulent condition, hantavirus cardiopulmonary syndrome (HCPS) or hantavirus pulmonary syndrome (HPS), resulting in an initial case fatality rate of $80 \%$ (CDC, 1993). It is hypothesized that the initial emergence event followed El Nino-Southern oscillation (ENSO), causing increased precipitation that resulted in increased rodent population densities and human interactions (Engelthaler et al., 1999). The majority of exposure is believed to occur indoors from contact with rodent excreta, at the interface of human settlement and natural ecosystem ecotone. A number of ecologically similar diseases, sharing rodent reservoirs and exposure, have also been recognized with increasing frequency worldwide and include Andes, Junin, Lanugan Negra, Lassa, Machupo, Puumala, Sabia, Seoul, Guanarito, Hantaan.

In areas in which livestock rearing is juxtaposed next to areas such as forests in which enzootic EIDs exist, the diseases may first spillover to domestic livestock and be amplified prior to additional spillover and emergence into human populations, such as in the case of human rabies outbreaks in northern Brazil (Gupta, 2005). Pigs may be involved as an intermediary step in a number of these instances including Nipah, Influenza, and Japanese Encephalitis. Spillover may also occur in both directions as illustrated by infectious agents as diverse as Echinococcus granulosus, Bacillus anthracis, Mycobacterium bovis, Rift Valley fever, Crimean-Congo hemorrhagic fever, and Kyasunur Forest virus. Animals congregate in ecotones, facilitating spillover. Possibly the best example is avian influenza, involving the mixing of three different communities: wild migratory waterfowl, wild local birds (and possible other vertebrates), and domestic fowl (chickens, geese, and ducks). In this case, all three of the above factors may combine to facilitate emergence. These affects may be further multiplied by the geographic convergence of aquatic-terrestrial ecotone with multiple types of humancreated ecotones, further intensifying ecotonal processes. Nutrient pollution, degradation of riparian habitat with associated loss of ecological functions that normally assimilate nutrients and pathogens, combined with concentration of domestic fowl and their waste are commonly associated with human settlement/aquatic-terrestrial ecotones. Added to this is the tendency for human land use, particular that associated with urbanization, to increase the variety and amount of runoff along with more erratic hydrology (Allen, 2004). Virtually all of the waterborne EIDs arguably are at least in part associated with aquaticterrestrial ecotonal processes, of which cholera and leptospirosis are well documented. Cholera ( $V$. cholerae, $V$. vulnificus, and $V$. parahaemolyticus) is associated both with the land-ocean ecotone (estuary), since marine crustaceans are their natural reservoirs, and terrestrial-freshwater ecotones where human settlement and rivers or wetlands converge as describe above. 


\section{CONCLUSION}

Ecotones have long been recognized as an important ecological setting favoring the transmission of a few well-described zoonotic infections, such as Yellow fever, where host or vector species congregate or otherwise occur in higher abundance than in either of the adjacent habitats. The ecotone concept as recently elaborated by landscape ecologists and the apparent correspondence with the biophysical and ecological evolutionary processes believed to generally underlie zoonotic EIDs may prove useful in better understanding the causes of the recently increasing global EID trend.

However, even for the 10 diseases identified here with a strong ecotone-association, ecotones may represent only one of several other important factors contributing to emergence. For example, human density, sanitation and hygiene, environmental quality, and pathogen dispersal, quite independent of ecotones and ecotonal processes, clearly contribute to the epidemiology of influenza, cholera, and malaria.

Also, the inclusiveness of landscape ecologists' expanded definition of ecotones and ecotonal processes, and the generality in terms of the association with disease emergence, arguably diminishes its predictive value. Specific ecotones will need to be more precisely defined, perhaps categorized or classified using landscape ecological methods, and such factors as intensity and concentration of the corresponding biophysical processes measured to develop predictive models of any practical utility based on the ecotone concept.

Yet ecotones apparently play a role in the some of the world's most important zoonotic EIDs. Current EID "hotspots" such as equatorial Africa and Southeast Asia seem to coincide with the pace of regional environmental change and its concomitants-urbanization, agricultural intensification, and habitat alteration (Wilcox and Colwell, 2005). That ecotones expand and ecotonal processes intensify with the creation and spread of multiple types of overlapping ecotones, as a result of and detectable by monitoring human activities such as land use, suggests the concept may be helpful in infectious disease research, surveillance, and prevention. The similar case made for their potential as sentinels for global climate change (Gosz, 1991, 1993; Allen and Breshears, 1998; Peteet, 2000) strengthens this argument.

\section{AcKNOWLedgments}

We thank Peter Daszak, Duane J. Gubler, and Durrell D. Kapan for comments on early versions of this article, along with helpful, critical discussions of the ecotone concept in relation to emerging zoonotic diseases.

\section{REFERENCES}

Allen CA, Breshears DD (1998) Drought-induced shift of a forest woodland ecotone: rapid landscape response to climate variation. Proceedings of the National Academy of Sciences of the United States of America 95:14839-14842

Allen JA (2004) Landscapes and riverscapes: the influence of land use on stream ecosystems. Annual Review of Ecology, Evolution and Systematics 35:257-284

Anyamba A, Linthicum KJ, Tucker CJ (2001) Climate-disease connections: Rift Valley fever in Kenya. Cadernos de Saude Publica 17(Suppl):133-140

Ashford RW (2000) The leishmaniases as emerging and reemerging zoonoses. International Journal for Parasitology 30:1269-1281

Barrett AD, Monath TP (2003) Epidemiology and ecology of yellow fever virus. Advances in Virus Research 61:291-315

Bennett SG, Webb JP, Madon MB, Childs JE, Ksiazek TG, TorrezMartinez N, et al. (1999) Hantavirus (Bunyaviridae) Infections in rodents from Orange and San Diego Counties, California. American Journal of Tropical Medicine and Hygiene 60:75-84

Boshel J (1969) Kyasanur Forest disease: ecologic considerations. American Journal of Tropical Medicine and Hygiene 18:67-80

Botto C, Escalona E, Vivas-Martinez S, Behm V, Delgado L, Coronel P (2005) Geographical patterns of onchocerciasis in southern Venezuela: relationships between environment and infection prevalence. Parassitologia 47:145-150

Boussinesq M, Gardon J (1997) Prevalences of Loa loa microfilaraemia throughout the area endemic for the infection. Annals of Tropical Medicine and Parasitology 91:573-589

Bradley DJ (2004) An exploration of chronotones: a concept for understanding the health processes of changing ecosystems. EcoHealth 1:165-171

Burg JG (2001) Seasonal activity and spatial distribution of hostseeking adults of the tick Dermacentor variabilis. Medical and Veterinary Entomology 15:413

Carlson J, Keating J, Mbogo CM, Kahindi S, Beier JC (2004) Ecological limitations on aquatic mosquito predator colonization in the urban environment. Journal of Vector Ecology 29:331-339

CDC (1993) Outbreak of acute illness-southwestern United States. MMWR. Morbidity and Mortality Weekly Report 42:421424

Chevalier V, de la Rocque S, Baldet T, Vial L, Roger F (2004) Epidemiological processes involved in the emergence of vectorborne diseases: West Nile fever, Rift Valley fever, Japanese encephalitis and Crimean-Congo haemorrhagic fever. Revue Scientifique et Technique (International Office of Epizootics) 23:535-555 
Clements FE (1905) Research Methods in Ecology. Lincoln, NE: The University Publishing Company

Daszak P, Cunningham AA, Hyatt AD (2000) Emerging infectious diseases of wildlife - threats to biodiversity and human health. Science 287:443-449

Daszak P, Tabor GM, Kilpatrick AM, Epstein J, Plowright R (2004) Conservation medicine and a new agenda for emerging diseases. Annals of the New York Academy of Sciences 1026:1-11

de Castro MC, Monte-Mor RL, Sawyer DO, Singer BH (2006) Malaria risk on the Amazon frontier. Proceedings of the National Academy of Sciences of the United States of America 103:24522457

de La Rocque S, Michel JF, Bouyer J, De Wispelaere G, Cuisance D (2005) Geographical Information Systems in parasitology: a review of potential applications using the example of animal trypanosomosis in West Africa. Parassitologia 47:97-104

de Thoisy B, Gardon J, Salas RA, Morvan J, Kazanji M (2003) Mayaro virus in wild mammals, French Guiana. Emerging Infectious Diseases 9:1326-1329

Eisen L, Eisen RJ, Lane RS (2004) The roles of birds, lizards, and rodents as hosts for the western black-legged tick Ixodes pacificus. Journal of Vector Ecology 29:295-308

Endy TP, Nisalak A (2002) Japanese encephalitis virus: ecology and epidemiology. Current Topics in Microbiology and Immunology 267:11-48

Engelthaler DM, Mosley DG, Cheek JE, Levy CE, Komatsu KK, Ettestad P, et al. (1999) Climatic and environmental patterns associated with hantavirus pulmonary syndrome, Four Corners region, United States. Emerging Infectious Diseases 5:87-94

Fagan WF, Cantrell RS, Cosner C (1999) How habitat edges change species interactions. The American Naturalist 153:165182

Fagbo SF (2002) The evolving transmission pattern of Rift Valley fever in the Arabian Peninsula. Annals of the New York Academy of Sciences 969:201-204

Field H, Young P, Yob JM, Mills J, Hall L, Mackenzie J (2001) The natural history of Hendra and Nipah viruses. Microbes and Infection 3:307-314

Fouchier RA, Rimmelzwaan GF, Kuiken T, Osterhaus AD (2005) Newer respiratory virus infections: human metapneumovirus, avian influenza virus, and human coronaviruses. Current Opinion in Infectious Diseases 18:141-146

Goddard J (1997) Clustering effects of lone star ticks in nature: implications for control. Environmental Health June:8-11

Gosz JR (1991) Fundamental ecological characteristics of landscape boundaries. In: Role of Landscape Boundaries in the Management and Restoration of Changing Environments, Ed MM, Holland RJN, Risser PG (editors), New York: Chapman and Hall, pp 8-10

Gosz JR (1993) Ecotone hierarchies. Ecological Applications 3:369376

Gupta R (2005) Recent outbreak of rabies infections in Brazil transmitted by vampire bats. Euro Surveillance:. Bulletin Européen sur les Maladies Transmissibles 10:E0511103

Hansen AJ, Castri F (1992) The environment and development crises as determinants of landscape dynamics. In: Landscape Boundaries: Consequences for Biotic Diversity and Ecological Flows, Ecological Studies, Castri AJHaFD (editor), New York: Springer-Verlag, pp 3-18

Hoberg EP, Kutz SJ, Nagy J, Jenkins E, Elkin B, Branigan M, et al. (2002) Protostrongylus stilesi (Nematoda: Protostrongylidae): ecological isolation and putative host-switching between Dallaposis sheep and muskoxen in a contact zone. Comparative Parasitology 69:1-9

Holland MM, Risser PG, Naiman RJ (1991) Ecotones: The Role of Landscape Boundaries in the Management and Restoration of Changing Environments. New York: Chapman and Hall

Jackson AC (2003) Rabies virus infection: an update. Journal of Neurovirology 9:253-258

Jenkins DJ, Romig T, Thompson RC (2005) Emergence/reemergence of Echinococcus spp.- - a global update. International Journal for Parasitology 35:1205-1219

Kapan DD, Bennett SN, Ellis BR, Fox J, Lewis ND, Spencer JH, et al. (2006) Avian influenza (H5N1) and the evolutionary and social ecology of infectious disease emergence. EcoHealth 3 (in press)

Khodakevich L, Szczeniowski M, Manbu-ma-Disu, Jezek Z, Marennikova S, Nakano J, et al. (1987) Monkeypox virus in relation to the ecological features surrounding human settlements in Bumba zone, Zaire. Tropical and Geographical Medicine 39:56-63

Lafferty KD, Kuris AM (1999) How environmental stress affects the impacts of parasites. Limnology and Oceanography 44:564-590

Lambin EF, Geist HJ, Lepers E (2003) Dynamics of land-use and land-cover change in tropical regions. Annual Review of Environment and Resources 28:205-241

Le Guenno B (1997) Haemorrhagic fevers and ecological perturbations. Archives of Virology Supplementum 13:191-199

Lederberg J, Shope RE, Oaks SC (2003) Emerging Infections: Microbial Threats to Health in the United States. Washington, DC: Institute of Medicine, National Academy Press

Leopold A (1933) Game Management. New York: Scribner's

Lindstrom A, Jaenson TGT (2003) Distribution of the common tick, Ixodes ricinus (Acari: Ixodidae), in different vegetation types in southern Sweden. Journal of Medical Entomology 40:373-378

Lipp EK, Huq A, Colwell RR (2002) Effects of global climate on infectious disease: the cholera model. Clinical Microbiology Reviews 15:757-770

LoGiudice K, Ostfeld RS, Schmidt KA, Keesing F (2003) The ecology of infectious disease: effects of host diversity and community composition on Lyme disease risk. Proceedings of the National Academy of Sciences of the United States of America 100:567-571

Lothrop HD, Lothrop B, Reisen WK (2002) Nocturnal microhabitat distribution of adult Culex tarsalis (Diptera: Culcidae) impacts control effectiveness. Journal of Medical Entomology 39:574-582

Maupin GO, Fish D, Zultowsky J, Campos EG, Piesman J (1991) Landscape ecology of Lyme disease in a residential area of Westchester County, New York. American Journal of Epidemiology 133:1105-1113

McCrae AW, Kirya BG (1982) Yellow fever and Zika virus epizootics and enzootics in Uganda. Transactions of the Royal Society of Tropical Medicine and Hygiene 76:552-562

Mercer DR, Castillo-Pizango MJ (2005) Changes in relative species compositions of biting midges (Diptera: Ceratopogonidae) and an outbreak of Oropouche virus in Iquitos, Peru. Journal of Medical Entomology 42:554-558

Meyer WB, Turner BL (1994) Changes in Land Use and Land Cover: A Global Perspective. New York: Cambridge University Press 
Michel AL (2002) Implications of tuberculosis in African wildlife and livestock. Annals of the New York Academy of Sciences 969:251-255

Moncayo AC, Fernandez Z, Ortiz D, Diallo M, Sall A, Hartman S, et al. (2004) Dengue emergence and adaptation to peridomestic mosquitoes. Emerging Infectious Diseases 10:1790-1796

Morner T (1992) The ecology of tularaemia. Revue Scientifique et Technique (International Office of Epizootics) 11:1123-1130

Munga S, Minakawa N, Zhou G, Mushinzimana E, Barrack OO, Githeko AK, et al. (2006) Association between land cover and habitat productivity of malaria vectors in western Kenyan highlands. American Journal of Tropical Medicine and Hygiene 1:69-75

Odum EP (1971) Fundamentals of Ecology. Philadelphia: Saunders

Olival KJ, Daszak P (2005) The ecology of emerging neurotropic viruses. Journal of Neurovirology 11:441-446

Parola P, Davoust B, Raoult D (2005) Tick- and flea-borne rickettsial emerging zoonoses. Veterinary Research 36:469-492

Patz JA, Daszak P, Tabor GM, Aguirre AA, Pearl M, Epstein J, et al. (2004) Unhealthy landscapes: policy recommendations on land use change and infectious disease emergence. Environmental Health Perspectives 112:1092-1098

Patz JA, Graczyk TK, Geller N, Vittor AY (2000) Effects of environmental change on emerging parasitic diseases. International Journal for Parasitology 30:1395-1405

Peiris JS, Amerasinghe FP, Arunagiri CK, Perera LP, Karunaratne SH, Ratnayake CB, et al. (1993) Japanese encephalitis in Sri Lanka: comparison of vector and virus ecology in different agroclimatic areas. Transactions of the Royal Society of Tropical Medicine and Hygiene 87:541-548

Peteet D (2000) Sensitivity and rapidity of vegetational response to abrupt climate change. Proceedings of the National Academy of Sciences of the United States of America 97:1359-1361

Pietzsch ME, Medlock JM, Jones L, Avenell D, Abbott J, Harding P, et al. (2005) Distribution of Ixodes ricinus in the British Isles: investigation of historical records. Medical and Veterinary Entomology 19:306-314

Powers AM, Brault AC, Tesh RB, Weaver SC (2000) Re-emergence of Chikungunya and O'nyong-nyong viruses: evidence for distinct geographical lineages and distant evolutionary relationships. Journal of General Virology 81:471-479

Risser PG (1995) The status of the science examining ecotones. Bioscience 45:318-326

Rodhain F (1980) [Hypotheses on the dynamic ecology of Loa infections]. Bulletin de la Société de Pathologie Exotique et de Ses Filiales 73:182-191

Rose JB (1997) Environmental ecology of Cryptosporidium and public health implications. Annual Review of Public Health 18:135-161

Rotureau B (2006) Ecology of the leishmania species in the Guianan ecoregion complex. American Journal of Tropical Medicine and Hygiene 74:81-96

Smith TB, Wayne RK, Girman DJ, Bruford MW (1997) A role for ecotones in generating rainforest biodiversity. Science 276:18551857

Steere AC, Cobur J, Glickstein L (2004) The emergence of Lyme disease. The Journal of Clinical Investigation 113:1093-1101

Svobodova M, Vorisek P, Votypka J, Weidinger K (2004) Heteroxenous coccidia (Apicomplexa: Sarcocystidae) in the popu- lations of their final and intermediate hosts: European buzzard and small mammals. ACTA Portozoologica 43:251-260

Taylor LH, Latham SM, Woolhouse ME (2001) Risk factors for human disease emergence. Philosophical Transactions of the Royal Society of London. Series B: Biological Sciences 356:983989

Townsend AK, Ostfeld RS, Geher KB (2003) The effects of bird feeders on Lyme disease prevalence and density of Ixodes scapularis (Acari:Ixodidae) in a residential area of Dutchess county, New York. Journal of Medical Entomology 40:540-546

Vinetz JM, Wilcox BA, Aguirre A, Gollin LX, Katz AR, Fujioka RS, et al. (2005) Beyond disciplinary boundaries: leptospirosis as a model incorporating transdisciplinary approaches to understanding infectious disease emergence. EcoHealth 2:291-306

Vittor AY, Gilman RH, Tielsch J, Glass G, Shields T, Lozano WS, et al. (2006) The effect of deforestation on the human-biting rate of Anopheles darlingi, the primary vector of falciparum malaria in the Peruvian Amazon. American Journal of Tropical Medicine and Hygiene 1:3-11

Walker S, Bastow J, Steel JB, Rapson GL, Smith B, King WM, et al. (2003) Properties of ecotones: evidence from five ecotones objectively determined from a coastal vegetation gradient. Journal of Vegetation Science 14:579-590

Walter A (2003) [Human activities and American trypanosomiasis. Review of the literature]. Parasite 10:191-204

Wanji S, Tendongfor N, Esum M, Atanga SN, Enyong P (2003) Heterogeneity in the prevalence and intensity of loiasis in five contrasting bioecological zones in Cameroon. Transactions of the Royal Society of Tropical Medicine and Hygiene 97:183-187

Wasteson Y (2001) Zoonotic Escherichia coli. Acta Veterinaria Scandinavica Supplementum 95:79-84

Weaver SC (2005) Host range, amplification and arboviral disease emergence. Archives of Virology Supplementum 33-44

Webster RG, Bean WJ, Gorman OT, Chambers TM, Kawaoka Y (1992) Evolution and ecology of influenza A viruses. Microbiological Reviews 56:152-179

Wilcox BA, Colwell RR (2005) Emerging and reemerging infectious diseases: biocomplexity as an interdisciplinary paradigm. EcoHealth 2:244-257

Wilcox BA, Gubler DJ (2005) Disease ecology and the global emergence of zoonotic pathogens. Environmental Health and Preventative Medicine 10:263-272

Wilson ME (2002a) Prevention of tick-borne diseases. The Medical Clinics of North America 86:219-238

Wilson ML (2002b) Emerging and vector-borne diseases: role of high spatial resolution and hyperspectral images in analyses and forecasts. Journal of Geographical Systems 4:31-42

Woolhouse ME, Gowtage-Sequeria S (2005) Host range and emerging and reemerging pathogens. Emerging Infectious Diseases 11:1842-1847

Yapi YG, Briet OJ, Diabate S, Vounatsou P, Akodo E, Tanner M, et al. (2005) Rice irrigation and schistosomiasis in savannah and forest areas of Cote d'Ivoire. Acta Tropica 93:201-211

Yuill TM (1986) The ecology of tropical arthropod borne viruses. Annual Review of Systematics and Ecology 17:189-219

Zeier M, Handermann M, Bahr U, Rensch B, Muller S, Kehm R, et al. (2005) New ecological aspects of hantavirus infection: a change of a paradigm and a challenge of prevention-a review. Virus Genes 30:157-180 